Journal of Qualitative Criminal Justice \& Criminology

\title{
Book Review | Gang Life in Two Cities: An Insider's \\ Journey
}

Robert Donald Weide ${ }^{1}$

${ }^{1}$ New York University

Published on: Apr 01, 2014

DOI: $10.21428 / 88 d e 04 a 1.0 f 414 d e d$

License: Creative Commons Attribution 4.0 International License (CC-BY 4.0). 
Robert J. Duran. Gang Life in Two Cities: An Insider's Journey. Columbia University Press, 2013; 253 pp.; ISBN: 9780231158664.

In his newly published book, former gang member and probation officer Robert J. Duran provides both a compelling comparative ethnography of gang life in two middle American cities, Denver, Colorado and Ogden, Utah, as well as a needed critical analysis of both the historical and contemporary roles of colonial oppression and law enforcement practices and policies that have contributed to the formation and perpetuation of gang identities in the barrios of those cities. Although neither cites the other's work, I think it is fair to cast Duran's book as a counterpart to Michelle Alexander's celebrated work The New Jim Crow (Alexander, 2010). While Alexander failed to consider the effect mass criminalization has on Latino communities in the US, Duran provides a beautiful description and critical analysis of just that. However, rather than focus on the war on drugs and a Jim Crow analogy as Alexander did, Duran relates the history of internal colonialism to the emergence of gang enforcement as a vehicle for continuing the oppression of communities of color in the post-civil rights era. This is an extremely important contribution to the literature not just on Latinos and/or gangs specifically, but to post-colonial theory, critical race theory, and critical criminology perspectives in totum. I can only hope that this significant piece enjoys the prominence that it deserves.

In addition to the content provided in this piece in terms of its ethnographic description and theoretical contributions, this work also provides another major academic contribution in its methodological approach. Duran is the first scholar with personal involvement in gangs to specifically study the gang life he himself participated in, richly incorporating his own personal experiences into his analysis. While renowned sociologist victor Rios (2011) also had a background in gang life, his book is not specifically focused on the topic of gangs, nor does he discuss his own involvement to any significant degree. In contrast, Duran's book boldly makes his own prior gang membership and his racial/ethnic identity as a Latino the focal point of his work, both descriptively and theoretically. He consciously relates this approach to critical race theory (CRT) perspectives, which argue that those from privileged backgrounds cannot fully appreciate the experiences of marginalized minority populations, and that it takes someone who has suffered those experiences personally to accurately analyze their effect. With the perspective that only a true insider can possess, Duran is able to assemble an array of sources, both historical and contemporary, to support his comprehensive narrative of gang life in the barrios of Denver and Ogden. Duran's career as a scholar, and this important work arising out of his dissertation research, are the culmination of a vision his mentor Patricia Adler and her husband Peter Adler have been advocating for decades now, starting most significantly with their seminal methodological contribution in 1987, Membership Roles in Field Research. Duran is a living embodiment of the complete membership role advocated by Adler and Adler in that 
classic piece and the strength of his analysis demonstrates the efficacy of complete membership as a primary ethnographic strategy.

While Sanchez-Jankowski has claimed to have assumed a membership role in his research on gangs in his 1991 book, Islands in the Street, it is impossible to verify the veracity of his claims, for he refused to reveal which gangs his research was conducted with, ostensibly under the questionable Chicago School assumption that in order to protect subjects, researchers cannot even identify which specific groups they studied, in addition to hiding the identities of individual subjects, which is, of course, ethically required. Rios also follows in this path, repeatedly refusing to identify which groups are the subjects of his research. This flawed perspective of refusing to enable the replication or verification of their research, even by other researchers, leaves serious and lingering doubts about the veracity of their research and findings and undermines the fundamental intent of the scientific method which requires that any finding(s) be subject to replication and verification. Not so with Duran, who courageously casts off the yolk of undue secrecy and takes the bold step of discussing specific gangs in specific circumstances, even to the point of discussing his own past involvement. This specificity of analysis gives his analysis a depth that previous research has not been able to attain and enables his narrative to ring true not just to an elite academic audience, but also to the very marginalized populations that his research engages with.

Faithfully adhering to C. Wright Mills' (1959/2000) exhortation that sociological research necessarily include the consideration of historical factors that structured contemporary circumstances, Duran provides a richly detailed comparative historical background to both of this field sites, Denver and Ogden. This adroit historical analysis results in a comparison more than a contrast between the two sites; Duran finds that the historical experience of internal colonization is endemic to barrio communities in both barrio milieus. The consistency of his findings across these two seemingly disparate settings further substantiates his overall argument that the root causes of the emergence and persistence of gangs in marginalized barrio communities throughout the American Southwest is due to the history of internal colonialism that barrio populations have suffered since the sacrifice of the entire Southwest at the altar of manifest destiny upon the conclusion of the Mexican American War in the mid-19th century. Thus, his findings and analysis have strong validity in terms of generalizability to other similar locales throughout the American Southwest.

Another important contribution Duran makes is to explore the experience of barrio residents, particularly the youth, as the objects of heightened scrutiny from law enforcement agencies. Duran argues that modern law enforcement practices and policies effectively operate to marginalize and subjugate barrio youth, under the unassailable auspices of suspected or alleged gang involvement, rather than under the brazen racial or colonial regimes of past eras. Using thick ethnographic description and numerous quotes from formal interviews, Duran proceeds to argue that this hyper- 
criminalization of young barrio residents has the inadvertent result of causing gang members to cling to their gang identities rather than abandoning them. These findings are firmly in line with those of Rios and other critical scholars of urban policing, who have pointed to the role overzealous law enforcement play in perpetuating deviant identities in marginalized urban youth populations.

Perhaps most notably, citing such icons of the radical left such as Franz Fanon, Che Guevara and Karl Marx, Duran offers a critical neo-Gramscian analysis of the hegemonic role of criminal gang involvement as a justification for the continued oppression of marginalized barrio youth populations and their communities. According to Duran's dialectic analysis, while marginalized barrio communities are criminalized under the auspices of gang enforcement, gang members' criminal behavior provides the justification used for their continued hyper-policing. This vicious cycle renders gang members the instruments of their own oppression, unwittingly providing the justification for their own continued subjugation. This is perhaps his most valuable contribution to critical theoretical perspectives on race and crime.

However, there are a few minor criticisms that I might offer for the reader to consider. The first critique I have is that the historical analyses of Denver and Ogden should have followed the introduction and methodology chapters, with the chapter on policing gangs moved to just before the second to last chapter on the persistence of gang identities. There is a bit of a disconnect between these two important chapters with three other chapters in between them by my reading, but of course hindsight is always $20 / 20$.

Another trivial critique is that the vast majority of the interview quotes are taken from only a handful of respondents. With over one hundred subjects interviewed for the project, it would have been better to get a more extensive representation of the perspectives of a wider swath of the subject population. However, as a qualitative researcher myself, I can certainly appreciate that for every subject who opens up and shares his/her world with you, there can be others for whom getting any usable data out of them is be like pulling teeth with a pair of pliers. So in a sense, I sympathize with Duran's choice to collect and present a large amount of data from the limited number of respondents who were willing to discuss their perspectives openly and who had something worth saying.

Another critique I think Duran's book shares with Michelle Alexander's is that it only really deals with the experiences of one racial group and one form of criminalization, in this case Latino barrio populations and criminalization, through alleged or suspected gang involvement. Taken together, the two works provide a compelling narrative of the oppression of marginalized communities of color in the contemporary United States; however, individually, each is left lacking.

Finally, while Alexander utterly ignored CRT perspectives that were logical predecessors to her argument, Duran made a conscious effort to engage with CRT literature as a frame for both his 
methodological approach and his critical analysis. However, I felt that he could have incorporated CRT perspectives to a greater degree than he did, since he made only passing reference to minimal CRT citations and no serious review or engagement with what is now a significant body of CRT literature. While Duran has laid the foundation for a bridge between CRT perspectives presented by legal scholars and modern social science research, the work of building that bridge remains to be completed. Duran also curiously omits a citation for Gramsci himself, though he regularly references Gramsci's concept of hegemony.

All in all, I believe Duran's work to be a valuable contribution to the literature on gangs specifically and to critical theoretical perspectives on race and deviant subcultures in general, from post-colonial theory, to critical race theory, to critical criminology perspectives. It is an enjoyable read and a fine pedagogical tool for exposing students to the experiences of marginalized minority populations in the barrios of the Southwestern United States.

\section{References}

Adler, P. A. \& Adler, P. (1987). Membership roles in field research. Qualitative Research Methods Series Volume 6. Thousand Oaks, CA: Sage Publications.

Alexander, M. (2010). The new jim crow: Mass incarceration in the age of colorblindness. New York, NY: The New Press.

Mills, C. W. (1959/2000). The sociological imagination. Oxford, UK: Oxford University Press.

Rios, V. (2011). Punished: Policing the lives of black and latino boys. Berkeley CA: University of California Press.

Sanchez-Jankowski, M. (1991). Islands in the street: Gangs and American urban society. Berkeley CA: University of California Press. 